\title{
Hot Water and Copper Coatings in Reused Containers Decrease Inoculum of Fusarium and Cylindrocarpon and Increase Douglas Fir Seedling Growth
}

\author{
R. Kasten Dumroese ${ }^{1}$ \\ United States Department of Agriculture Forest Service, Southern Research \\ Station, 1221 S. Main Street, Moscow, ID 83843
}

\author{
Robert L. James ${ }^{2}$ \\ U.S. Department of Agriculture Forest Service, Forest Health Protection, \\ Coeur d'Alene, ID
}

\author{
David L. Wenny ${ }^{3}$ \\ Forest Research Nursery, Department of Forest Resources, University of \\ Idaho, Moscow, ID
}

Additional index words. root disease, integrated pest management, fungicide, Pseudotsuga menziesii

\begin{abstract}
Inoculum of Douglas fir root diseases caused by the fungi Fusarium and Cylindrocarpon is carried from crop to crop in reused containers. Soaking containers for 90 seconds in $80{ }^{\circ} \mathrm{C}$ water removed $\approx 99 \%$ of Fusarium and $100 \%$ of Cylindrocarpon inoculum between growing cycles. Overall seedling growth was also improved: seedlings grown in containers soaked between growing cycles were $10 \%$ taller and had $20 \%$ more biomass than seedlings grown in nonsoaked containers. We obtained a $13 \%$ increase in the number of deliverable seedlings from containers soaked in hot water between crops, from the use of copper coated containers, or from both practices combined.
\end{abstract}

Douglas fir [Pseudotsuga menziesii (Mirbel) Franco] is commonly grown for reforestation in the northern Rocky Mountains and Pacific Northwest. Seedlings are usually grown as a 1-year crop at high densities (up to 1076 seedlings $/ \mathrm{m}^{2}$ ) in styrofoam or hard plastic containers that are reused for several crops. Seedling production in containers is often hampered by Fusarium root disease (James et al., 1987), and losses vary with seedlot and nursery. Fusarium proliferatum (Matsushima) Nirenberg is the most common species, and often the most virulent pathogen, infesting containers and colonizing seedlings (Dumroese et al., 1993; James et al., 1997). Another root pathogen found in nursery environments is Cylindrocarpon (Beyer-Ericson et al., 1991), commonly found in the rhizosphere of container-grown conifer nursery stock (James et al., 1994; Kope et al., 1996). Many Cylindrocarpon sp. are readily isolated from roots of symptomatic and nonsymptomatic seedlings in inland Pacific Northwest nurseries

\footnotetext{
Received for publication 13 Nov. 2001. Accepted for publication 18 Jan. 2002. We thank K.E. Quick and S.J. Morrison at the Research Nursery for their technical assistance; D. Gerdes and Silvaseed Co. for providing containers; the Idaho Dept. of Lands for financial assistance; K. Steinhorst for assistance with statistical analysis; and R.R. Tripepi, G. Newcombe, B. Maynard, and E. Hinesley, and the anonymous reviewers for their comments on earlier drafts. ${ }^{1}$ Plant Physiologist.

${ }^{2}$ Plant Pathologist.

${ }^{3}$ Professor/Director.
}

(James et al., 1994). Often, infected plants lack aboveground symptoms (e.g., chlorotic or necrotic foliage) despite extensive root decay. Cylindrocarpon sp. may act in conjunction with other root pathogens to cause major disease problems (Bloomberg and Sutherland, 1971; Duda and Sierota, 1987).

Generally, root disease is difficult to control because root systems usually are extensively colonized before shoot symptoms appear (James et al., 1987), and chemical fungicide applications are generally ineffective (James, 1986a; James et al., 1988b). Therefore, integrated pest management is the best alternative to control root disease (James et al., 1990).

Reducing inoculum of pathogenic organisms is important for limiting seedling infection (James et al., 1990). Although seeds may be an important source of Fusarium (James, 1986b), inoculum may also be carried from crop to crop on interior walls of reused containers (James et and Dennis, 1988), and it may be particularly concentrated at the bottom of containers (James, 1989; James and Gilligan, 1988b).

Immersion in hot water is a common method to sterilize plastic pots (Hartmann et al., 1990) and works well for both styrofoam and plastic containers used in reforestation nurseries (Sturrock and Dennis, 1988; James, 1989; James and Woollen, 1989). In forest nursery situations, hot water is preferable to chemical treatments such as sodium metabisulfite or bleach solutions due to reduced potential for worker exposure to irritating or toxic chemial., 1988a; James and Gilligan, 1988a; Sturrock cals, problems of chemical disposal, and higher efficacy against pathogens (Dumroese et al., 1993; James and Sears, 1990; Peterson 1990, 1991).

Another potential problem with containergrown seedlings is poor root egress from the upper portions of the root plug after planting (Burdett, 1978, 1979a). New roots often fail to grow in a natural pattern (Balisky et al., 1995) that can affect seedling stability (Burdett, 1978) and may limit seedling access to nutrients, water, and mycorrhizal inoculum (Dumroese, 2000). Researchers have found a coating of copper on interior surfaces of containers changes Douglas fir root morphology at the nursery and improves root egress and form after outplanting (Burdett, 1978; Burdett and Martin, 1982; Wenny et al., 1988; Wenny and Woollen, 1989). This technique is also effective on many other horticultural plants (Appleton, 1993; Arnold, 1996; Brass et al., 1996).

In a pilot study, a copper-coating was also effective in reducing seedling infection and colonization by $F$. proliferatum (Dumroese et al., 1995). This was not surprising since copper is also one of the oldest and most effective fungicides (Pirone, 1978). Copper sulfate and lime (Bordeaux mixture) has widespread toxicity against many plant pathogenic fungi (Johnson, 1935), cuprous oxide effectively protects seeds against seed-borne pathogenic fungi (Horsfall, 1932), and several other insoluble copper compounds, applied as sprays or dusts, protect plants against pathogens (Walker, 1969). Although toxic at high concentrations, copper is an essential nutrient for Fusarium sp. at low concentrations (Steinberg, 1950; Woltz and Jones, 1981).

Our objectives were to quantify the rate of fungal inoculum build-up on reused seedling containers, how that affected seedling growth, and compare the efficacy of hot water treatments with the copper-coated containers for controlling fungal inoculum in a commercial nursery setting.

\section{Materials and Methods}

Our experiment was a completely randomized two container type $\times$ two cleaning treatment factorial arrangement conducted for five growing cycles. The two container types were Styroblock and Copperblock containers that were identical (160 cavities per container aligned in 10 rows and 16 columns, $90-\mathrm{mL}$ cavity volume, and 764 cavities per $\mathrm{m}^{2}$; Beaver Plastics, Edmonton, Alberta, Canada) except that Copperblocks have a proprietary copper oxychloride coating on cavity walls. Cleaning treatments were either no container cleaning (control) or submerging (soaking) containers in hot water $\left(77\right.$ to $82^{\circ} \mathrm{C}$ ) for $90 \mathrm{~s}$. We assigned three containers to each container type-soaking combination to serve as replicates and these containers remained within that treatment for five growing cycles. For each 10-month growing cycle, the same northern Idaho source of Douglas fir was sown in March and seedlings were harvested in December. We randomly placed all con- 
tainers within a production crop of Douglas fir at the Univ. of Idaho Forest Research Nursery that were grown following our basic regime (Wenny and Dumroese, 1992) and without fungicides. Seedlings were grown the first two growing cycles in a 1 sphagnum peat moss : 1 vermiculite $(\mathrm{v} / \mathrm{v})$ growing medium in a fullyenclosed greenhouse. We grew seedlings the final three growing cycles in a 7 sphagnum peat moss : 3 Douglas fir sawdust (v/v) medium; seedlings were started inside the greenhouse and moved to an open-sided greenhouse when seedlings were at $\approx 75 \%$ of target height.

After each growing cycle and from a randomly-selected starting point, we systematically extracted 20 seedlings from each container (60 seedlings per container typesoaking combination), avoiding seedlings in the outer two rows and two columns to minimize edge effects. Seedlings were classified as deliverable or cull based on nursery criteria: stem diameter $>2.3 \mathrm{~mm}$; height $>15 \mathrm{~cm}$, but $<30 \mathrm{~cm}$; and firm root plug. Roots were gently washed to remove adhering medium. We measured seedling root volume using Burdett's (root collar to tip of terminal bud), and stem diameter at the root collar (RCD). From each seedling, 10 root tips, each $\approx 1 \mathrm{~cm}$ long, were randomly removed, surface sterilized in a 1 bleach $(5.25 \%$ sodium hypochlorite) : 10 water $(\mathrm{v} / \mathrm{v})$ solution for $1 \mathrm{~min}$, rinsed in sterile water, and aseptically placed on a Komada's selective medium (Komada, 1975). Root tips were incubated under cool-white fluorescent, diurnal light (12-h photoperiod) at 22 to $24^{\circ} \mathrm{C}$ for $7 \mathrm{~d}$. Although isolations were made onto Komada's medium which was initially designed to isolate Fusarium oxysporum
Schlect. from natural soil (Komada, 1975), our subsequent work indicated that this medium is selective for other Fusarium sp. (James et al., 1989, 1997), Cylindrocarpon sp. (Dumroese et al., 2000; James et al., 1997), and Trichoderma sp. (Mousseaux et al., 1998) as well.

Fungal identification involved obtaining single-spore isolates from colonies on Komada's medium and culturing them on both carnation leaf agar (Fisher et al., 1982) and potato dextrose agar. Fusarium species were identified based on the presence or absence of chlamydospores, macroconidial morphology, and the production of microconidia on chains or in false heads borne on mono- or polyphialides (Nelson et al., 1983). Cylindrocarpon sp. were identified using Booth's (1966) taxonomy; our identifications were based on macroconidial morphology, length, and septations and presence or absence of microconidia and chlamydospores. Seedlings were classified as infected if one or more root tips were colonized. Percent colonization was calculated by dividing the number of root tips infected by the total number of root tips sampled for all seedlings within the treatment. Seedling biomass was determined after drying shoots and roots at $60^{\circ} \mathrm{C}$ to constant weight.

One month after seedlings were extracted from containers, we assayed containers for residual Fusarium inoculum. Two pieces of styrofoam, each $\approx 0.5 \mathrm{~cm}^{3}$, were removed from the bottom drainage hole of 10 randomly selected cavities per container (30 cavities per container/soaking combination), placed on Komada's selective medium and incubated as described above. Immediately after sampling, containers assigned to the soaking treatment were immersed, allowed to dry, and then the same cavities were resampled to assess the efficacy of the soak. This technique did not affect the ability of individual cavities to hold medium in subsequent cycles.

Statistical analysis. Percentage data were transformed using the arcsin of the square root of the value. We used a general linear model (PROC GLM; SAS Institute, 1989). The error term for main effects (container type and soaking) was the residual variation of these variables averaged over time (cycles). Treatment means were separated using Tukey's honestly significant different test (HSD) when $P \leq 0.05$. Data were back transformed as necessary for tables.

\section{Results}

Seedling morphology. The interactions of cycle $\times$ container type and cycle $\times$ soak were both significant for height and RCD (Table 1) and the trend was the same: heights and RCDs were similar the first two cycles regardless of container type or soak, but seedlings the last three cycles were $5 \%$ taller with $12 \%$ thicker stems when grown in Copperblocks or $16 \%$ taller with $10 \%$ thicker stems when grown in soaked containers. The cycle $\times$ container type interaction was significant for shoot weight and root volume: shoot weight was reduced $13 \%$ the first cycle in Copperblocks when compared to Styroblocks, but subsequently Copperblocks yielded seedlings with $15 \%$ heavier shoots. Likewise, root volume was $8 \%$ lower for seedlings grown in Copperblocks the first two cycles but $8 \%$ higher the last three cycles when compared to Styroblocks.

The soak $\times$ container type interaction was

Table 1. Sources of variation and $P$ values for Douglas fir seedling morphological characteristics and number of deliverable seedlings when new crops of seedlings were grown in each of five growing cycles in reused Styroblock or Copperblock containers either soaked or not soaked in hot water between cycles.

\begin{tabular}{lcllcccc}
\hline \hline Source of variation & df & Height & RCD & Shoot wt & Root wt & Root volume & $\begin{array}{c}\text { Deliverable } \\
\text { seedlings }\end{array}$ \\
\hline Container & 1 & 0.3 & 0.01 & 0.3 & 0.8 & 0.8 & 0.0006 \\
Soak & 1 & 0.0005 & 0.003 & 0.0001 & 0.0006 & 0.02 & 0.002 \\
Soak $\times$ container & 1 & 0.007 & 0.02 & 0.002 & 0.008 & 0.03 & 0.0006 \\
Replicate $($ soak $\times$ container) & 2 & 8 & & & & & \\
Cycle & 4 & 0.0001 & 0.0001 & 0.0001 & 0.002 & 0.0001 & 0.003 \\
Cycle $\times$ soak & 4 & 0.03 & 0.03 & 0.7 & 0.3 & 0.3 & 0.005 \\
Cycle $\times$ container & 4 & 0.04 & 0.0008 & 0.04 & 0.3 & 0.01 & 0.2 \\
Cycle $\times$ soak $\times$ container & 4 & 0.2 & 0.8 & 0.99 & 0.8 & 0.8 & 0.07 \\
Error & 32 & & & & & &
\end{tabular}

${ }^{\mathrm{z}}$ The error term for main effects (container type and soaking) was the residual variation of these variables averaged over time (cycles).

Table 2. Means $( \pm \mathrm{sD})$ of Douglas fir seedling morphological characteristics and number of deliverable seedlings averaged over five growing cycles when new cops were grown each cycle in reused containers either soaked or not soaked in hot water between cycles.

\begin{tabular}{|c|c|c|c|c|c|c|}
\hline Treatment & $\begin{array}{l}\text { Height } \\
(\mathrm{cm})\end{array}$ & $\begin{array}{l}\mathrm{RCD} \\
(\mathrm{mm})\end{array}$ & $\begin{array}{l}\text { Shoot wt } \\
(\mathrm{g})\end{array}$ & $\begin{array}{c}\text { Root wt } \\
(\mathrm{g})\end{array}$ & $\begin{array}{l}\text { Root volume } \\
\text { (cc) }\end{array}$ & $\begin{array}{l}\text { Deliverable } \\
\text { seedlings (n) }\end{array}$ \\
\hline $\begin{array}{l}\text { No soak } \\
\text { Soak }^{y}\end{array}$ & $\begin{array}{l}20.7 \pm 6.0^{z} \\
24.3 \pm 4.1\end{array}$ & $\begin{array}{l}2.56 \pm 0.43 \\
2.86 \pm 0.32\end{array}$ & $\begin{array}{l}\text { Styroblock } \\
0.99 \pm 0.28 \\
1.35 \pm 0.30\end{array}$ & $\begin{array}{l}0.74 \pm 0.13 \\
0.92 \pm 0.08\end{array}$ & $\begin{array}{l}3.13 \pm 0.77 \\
3.82 \pm 0.69\end{array}$ & $\begin{array}{l}110 \pm 10 \\
124 \pm 4\end{array}$ \\
\hline $\begin{array}{l}\text { No soak } \\
\text { Soak }\end{array}$ & $\begin{array}{l}22.5 \pm 3.9 \\
23.3 \pm 3.8\end{array}$ & $\begin{array}{l}2.82 \pm 0.24 \\
2.88 \pm 0.21\end{array}$ & $\begin{array}{l}\text { Copperblock } \\
1.16 \pm 0.14 \\
1.25 \pm 0.19\end{array}$ & $\begin{array}{l}0.81 \pm 0.10 \\
0.84 \pm 0.11\end{array}$ & $\begin{array}{l}3.42 \pm 0.46 \\
3.48 \pm 0.48\end{array}$ & $\begin{array}{l}125 \pm 6 \\
124 \pm 7\end{array}$ \\
\hline
\end{tabular}

${ }^{\mathrm{z}} \mathrm{n}=300$ for height, RCD, shoot and root weight, and root volume for each treatment. For deliverable seedlings, the value shown is the mean number of seedlings considered deliverable per container (160 cavities) per treatment over all growing cycles.

${ }^{y}$ Submerged in hot water $\left(77\right.$ to $\left.82^{\circ} \mathrm{C}\right)$ for $90 \mathrm{~s}$ between growing cycles. 
Table 3. Morphological characteristics of Douglas fir seedlings averaged over five growing cycles when new crops of seedlings were grown in reused containers either soaked or not soaked in hot water between cycles.

\begin{tabular}{lccccc}
\hline Treatment & Height $(\mathrm{cm})$ & RCD $(\mathrm{mm})$ & Shoot wt $(\mathrm{g})$ & Root wt $(\mathrm{g})$ & Root volume $(\mathrm{cc})$ \\
\hline No soak & $21.6^{\mathrm{z}}$ & 2.69 & 1.07 & 0.77 & 3.3 \\
Soak & 23.8 & 2.87 & 1.30 & 0.88 & 3.6 \\
$P$ value & 0.07 & 0.04 & 0.02 & 0.003 & 0.005 \\
\hline
\end{tabular}

${ }^{\mathrm{z}} \mathrm{n}=600$ for each treatment.

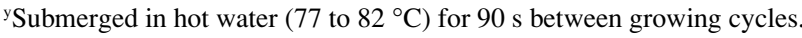

significant for all characteristics (Table 1). In general, Copperblocks yielded similar seedlings with or without soaking, whereas Styroblocks soaked in hot water yielded larger seedlings than nontreated Styroblocks (Table 2). For morphology characteristics, seedlings were significantly larger when grown in containers soaked in hot water between cycles (Table 3).

Container infestation. We isolated seven Fusarium sp. from containers and seedlings: $F$. acuminatum Ell. \& Ev., F. avenaceum (Fr.) Sacc., F. graminearum Schwabe., F. oxysporum, $F$. proliferatum, $F$. sambucinum Fuckel, and $F$. sporotrichioides Sherb. The three-way interaction of cycle, container type, and soak was significant for container infestation by Fusarium sp., but not for $F$. proliferatum (Table 4). Cycle interacted significantly with both container and soaking for Fusarium sp. and $F$. proliferatum (Table 4 ). Copperblocks had half the level of Fusarium sp. infestation for the first three growing cycles when compared to Styroblocks, but levels were similar the final two cycles. Conversely, soaked and nonsoaked containers had similar Fusarium sp. infestation after the first cycle but thereafter residual inoculum levels in soaked containers were about half those of nonsoaked containers. Growing cycle was significant (Table $4)$. The two-way interaction of container and soak was nonsignificant (Table 4), but overall, soaking was significant as nonsoaked containers were infested more $(86 \%)$ than those soaked (59\%).

For Cylindrocarpon, cycle interacted significantly with soak (Table 4): Cylindrocarpon was absent on cavity walls the first three growing cycles but $45 \%$ and $25 \%$ of the cavities were infested, respectively, the last two cycles. A soak $\times$ container type interaction was lacking and container type was not sig- nificant (Table 4). However, significantly higher amounts of Cylindrocarpon were found on seedlings growing in soaked containers $(34 \%)$ than nonsoaked containers $(13 \%)$.

After soaking, the number of cavities infested with Fusarium sp., F. proliferatum, or Cylindrocarpon ranged from $0 \%$ to $3 \%$ and none of the interactions or main effects were significant. We failed to isolate Cylindrocarpon sp. after soaking (data not shown).

Seedling infection and colonization. Cycle interacted significantly with soak for seedling infection and colonization by Fusarium sp. and Cylindrocarpon sp. (Table 4). After the first growing cycle, seedling infection and colonization by $F$ usarium $\mathrm{sp}$. was $\approx 2 \times$ greater on seedlings growing in containers to be soaked (64\% infection; $24 \%$ colonization) than in the control; in the next three growing cycles, infection and colonization were similar and high $(90 \%+$ infection; $\approx 60 \%$ colonization $)$ regardless of soaking treatment. After the final growing cycle, infection and colonization were very low but $2 \times$ greater in the nonsoaked containers $(\approx 29 \%$ infection; $\approx 8 \%$ colonization). For Cylindrocarpon sp., infection and colonization started at very low levels $(\approx 10 \%$ infection; $\approx 5 \%$ colonization) regardless of treatment and steadily increased with additional growing cycles; ranks changed annually between seedlings growing in soaked and nonsoaked containers. However, by the end of the fifth cycle, seedling infection and colonization by Cylindrocarpon sp. was similar and very high $(99 \%+$ infection and $\approx 66 \%$ colonization) for both treatments. As was the case with other variables, growing cycle was significant (Table 4). Except for container type significantly affecting infection by Cylindrocarpon sp., all other sources of variation lacked significance (Table 4). Overall, seedlings grown in Copperblocks had higher infection levels by Cylindrocarpon sp. $(54 \%)$ than those grown in Styroblocks (46\%).

Deliverable seedlings. Because containers were new and yet to be soaked, it was not surprising that similar numbers of seedlings were deliverable at the end of the first cycle regardless of treatment. Thereafter, more seedlings were deliverable in soaked containers $(5 \%, 3 \%, 15 \%$, and $5 \%$ for cycles $2,3,4$, and 5 , respectively) resulting in a significant cycle $\times$ soak interaction (Table 1 ). Numbers of seedlings that were deliverable in Copperblocks (regardless of soaking treatment) and the soaked Styroblocks were similar and higher than nonsoaked Styroblocks, leading to a significant soak $\times$ container type interaction (Tables 1 and 2). On average, Copperblocks and Styroblocks soaked in hot water yielded $13 \%$ more deliverable seedlings than nonsoaked Styroblocks (Table 2).

\section{Discussion}

The reductions in seedling growth during the first two growing cycles in Copperblocks were expected, as other studies at our nursery using Copperblocks have yielded similar results (Dumroese et al., 1995; Dumroese, 2000). Generally, the reduced growth is thought to be either copper phytotoxicity or nutritional problems due to the copper ions, which can be avoided by modifying the fertilizer regime (Landis and van Steenis, 2000; van Steenis, 1994). We speculate the nutritional aspect is more likely as Hunt (1990) found significantly better height, stem diameter, and shoot weights when Douglas fir seedlings were grown in Copperblocks. Further, Copperblocks in this study were interspersed among a production lot being grown with a fertilizer regime specific for Styroblocks. Moreover, other studies at the Univ. of Idaho showed that Douglas fir seedlings treated with cupric carbonate had similar height, RCD, and biomass to controls (Wenny and Woollen, 1989; Woollen, 1986). Since copper oxychloride is more soluble than cupric carbonate, it is likely that medium chemistry, nutrient availability, and subsequent seedling growth would be impacted more by this form of copper. Despite this temporary growth reduction that did not reduce the number of deliverable seedlings and that could probably be ameliorated by adjustments to the fertilizer

Table 4. Sources of variation and $P$ values for container infestation and Douglas fir seedling infection and colonization by Fusarium sp., F. proliferatum, and Cylindrocarpon sp. when new crops of seedlings were grown in each of five growing cycles in reused Styroblock or Copperblock containers either soaked or not soaked in hot water between cycles.

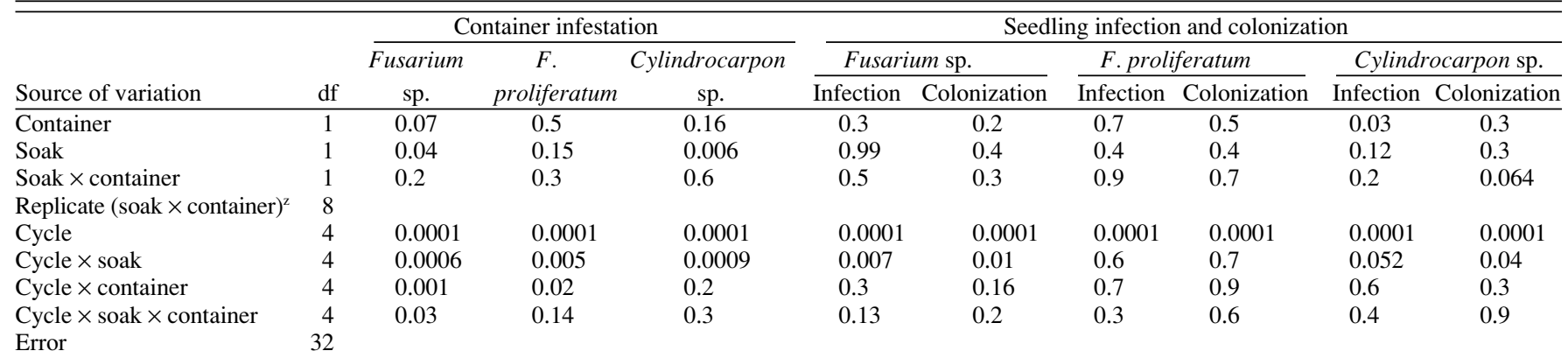

${ }^{2}$ The error term for main effects (container type and soaking) was the residual variation of these variables averaged over time (cycles). 
regime (van Steenis, 1994), seedling growth in the latter growing cycles was enhanced, perhaps because of reductions in fungal inoculum afforded by the copper.

Soaking containers in hot water was effective in reducing fungal inoculum, particularly with Cylindrocarpon sp. Our 90s soak at $80{ }^{\circ} \mathrm{C}$ removed $100 \%$ of Cylindrocarpon, much better than the $35 \%$ effectiveness reported with a 10-s dip at the same temperature (Peterson, 1991). Previous work indicated that optimum soaking temperatures vary by soaking duration (James and Woollen, 1989; Sturrock and Dennis, 1988). Despite inoculum reductions, Fusarium levels rebounded during subsequent growing cycles, but never to the level found in non-soaked containers. Because Fusarium is ubiquitous and inoculum may be introduced in a variety of ways, high levels of F usarium isolated from soaked containers at the end of a growing cycle was not surprising. As might be expected, high container infestation, regardless of treatment, also resulted in high seedling infection rates and colonization levels.

A problem with this type of work is correlating seedling infection by the organisms and subsequent disease expression. Fusarium isolates often display a wide range of virulence (James et al., 1986; Tint, 1945), but most isolates readily colonize cortical cells of seedling roots (Bloomberg, 1966; James and Gilligan, 1988c). Bloomberg and Lock (1972) concluded that several different diseases of conifer seedlings were probably caused by different strains of $F$. oxysporum. Further, virulent isolates may be collected from nonsymptomatic seedlings whereas nonpathogenic isolates can be found on dead or dying seedlings (James et al., 1989). Some isolates might become aggressive pathogens only when host seedlings are stressed (Bloomberg, 1971, 1973).

The lack of significant differences between container types and soaking treatments in regard to Fusarium sp., $F$. proliferatum, and Cylindrocarpon sp. infection and colonization of seedlings reaffirms our difficulties in correlating organisms and populations and their impacts on seedling crops. Despite this, it appears that soaking containers or coating them with copper will benefit growers because seedlings are larger and more are deliverable.

Economic implications. In the Pacific Northwest, Douglas fir seedlings grown in a standard container (the same container used in this study) sell for $\approx \$ 125$ per thousand. For a crop of 100,000 sown cavities, a nursery manager would need 625 containers. Currently, Copperblocks cost $32 \%$ more than Styroblocks so the Copperblocks would require an additional investment of $\approx \$ 812$. However, our data suggests that Copperblocks would yield an average of $13 \%$ more seedlings per growing cycle over five growing cycles compared to nontreated Styroblocks, requiring only an additional 1300 seedlings be produced annually in Copperblocks to justify the extra expense.

The economic return possible by soaking containers in hot water is more difficult to ascertain because of the vagaries of potential systems that could be employed to treat containers. Currently in the Pacific Northwest, many nurseries representing a range of annual seedling production from 300,000 or $12,000,000$ are soaking containers between crops. Some systems are very sophisticated while others are improvised. The Univ. of Idaho uses a natural-gas-heated tank into which a simple home-made metal cage holding 24 containers is lowered by hand (total cost of tank, materials, and labor for cage estimated at $\$ 5,000$ ). The University produces $\approx 600,000$ plants annually using two different containers $(\approx 7,000$ containers total $)$ with a retail value ranging from $\$ 280$ to $\$ 1,750$ per thousand. A two-person crew can load, soak, and unload 24 containers about every 10 min (including retrieval and delivery times with hand carts, waiting for the water to reach appropriate temperature, and so on) for a total labor cost of about $\$ 1,250$. Assuming a more conservative gain of $5 \%$ by soaking Styroblocks between cycles (rather than 13\% found in this study for the more susceptible Douglas fir), we estimate the annual retail value of the additional seedlings at $\approx \$ 23,000$, indicating the system would pay for itself after one growing cycle.

\section{Literature Cited}

Appleton, B.L. 1993. Nursery production alternatives for reduction or elimination of circling tree roots. J. Arbor. 19:383-387.

Arnold,M.A. 1996. Mechanical correction and chemical avoidance of circling roots differentially affect post-transplant root regeneration and field establishment of container-grown Shumard oak. J. Amer. Soc. Hort. Sci. 121:258-263.

Balisky, A.C., P. Salonius, C. Walli, and D. Brinkman. 1995. Seedling roots and forest floor: Misplaced and neglected aspects of British Columbia's reforestation effort? For. Chron. 71:59-65.

Beyer-Ericson, L., E. Dahm, and T. Unestam. 1991. An overview of root dieback and its causes in Swedish nurseries. Eur. J. For. Pathol. 21:439_ 443.

Bloomberg, W.J. 1966. The occurrence of endophytic fungi in Douglas-fir seedlings and seeds. Can. J. Bot. 44:413-320.

Bloomberg, W.J. 1971. Diseases of Douglas-fir seedlings caused by Fusarium oxysporum. Phytopathology 61:467-470.

Bloomberg, W.J. 1973. Fusarium root rot of Douglas-fir seedlings. Phytopathology 63:337-341.

Bloomberg, W.J. and W. Lock. 1972. Strain differences in Fusarium oxysporum causing diseases of Douglas-fir seedlings. Phytopathology 62:481-485.

Bloomberg, W.J. and J.R. Sutherland. 1971. Phenology and fungus-nematode relations of corky root disease of Douglas-fir. Ann. Appl. Biol. 69:265-276.

Booth, C. 1966. The genus Cylindrocarpon. The Commonwealth Mycological Institute. Mycological Papers No. 104. Kew, Surrey, England.

Brass, T., G. Keever, D.J. Eakes, and C. Gilliam. 1996. Styrene lined and copper coated containers affect production and landscape establishment of red maple. HortScience 31:353-356.

Burdett, A.N. 1978. Control of root morphogenesis for improved mechanical stability in containergrown lodgepole pine. Can. J. For. Res. 8:483486.
Burdett, A.N. 1979a. Juvenile instability in planted pines. Irish For. 36:36-47.

Burdett, A.N. 1979b. A nondestructive method for measuring the volume of intact plant parts. Can. J. For. Res. 9:120-122.

Burdett, A.N. and P.A.F. Martin. 1982. Chemical root pruning of coniferous seedlings. HortScience $17: 622-624$.

Duda, B. and Z.H. Sierota. 1987. Survival of Scots pine seedlings after biological and chemical control of damping-off in plastic greenhouses. Eur. J. For. Path. 17:110-117.

Dumroese, R.K. 2000. Changes in interior Douglasfir root development in containers after copper and auxin treatments. West. J. Appl. For. 15:213216.

Dumroese, R.K., R.L. James, and D.L. Wenny. 1993. Sodium metabisulfite reduces fungal inoculum in containers used for conifer nursery crops. Tree Planters' Notes 44:161-165.

Dumroese, R.K., R.L. James, and D.L. Wenny. 1995. Interactions between copper-coated containers and Fusarium root disease: a preliminary report. USDA For. Serv. North. Reg. For. Pest Mgt. Rpt. 95-9, Missoula, Mont.

Dumroese R.K., R.L. James, and D.L.Wenny. 2000. An assessment of Cylindrocarpon on container western white pine seedlings after outplanting. West. J. Appl. For. 15:5-7.

Fisher, N.L., L.W. Burgess, T.A. Toussoun, and P.E. Nelson. 1982. Carnation leaves as a substrate and for preserving cultures of Fusarium species. Phytopathology 72:151-153.

Hartmann, H.T., D.E. Kester, and F.T. Davis, Jr. 1990. Plant propagation-Principles and practices. 5th ed. Prentice Hall, Englewood Cliffs, N.J.

Horsfall, J.G. 1932. Red oxide of copper as a dust fungicide for combating damping-off by seed treatment. New York Agr. Expt. Sta. Bul. 615

Hunt, G.A. 1990. Effect of styroblock design and copper treatment on morphology of conifer seedlings. p. 218-222 In: R. Rose, S.J. Campbell, and T.D. Landis (eds.). Target seedling symposium: Proc., combined meeting of the Western Forest Nursery Assn. and Intermountain Nursery Assn. USDA For. Serv. Gen. Tech. Rpt. RM-200, Fort Collins, Colo.

James, R.L. 1986a. Occurrence of Fusarium on Douglas-fir seed and containerized seedlings at the Plum Creek Nursery, Pablo, Montana. USDA For. Serv. North. Reg. For. Pest Mgt. Rpt. 86-4, Missoula, Mont

James, R.L. 1986b. Diseases of conifer seedlings caused by seed-borne Fusarium species, p. $267-$ 271 In: R.C. Shearer (compiler). Proc. of the symposium on conifer tree seed in the Inland Mountain West. USDA For. Serv. Gen. Tech. Rpt. INT-203, Ogden, Utah.

James, R.L. 1989. Spatial distribution of fungi colonizing Leach pine cell containers-USDA Forest Service Nursery, Coeur d'Alene, Idaho. USDA For. Serv. North. Reg. For. Pest Mgt. Rpt. 90-3, Missoula, Mont.

James, R.L., R.K. Dumroese, C.J.Gilligan, and D.L. Wenny. 1989. Pathogenicity of Fusarium isolates from Douglas-fir seed and container-grown seedlings. Univ. of Idaho, Idaho For., Wildlife and Range Expt. Sta. Bul. 52, Moscow.

James, R.L, R.K. Dumroese, and D.L. Wenny. 1988a. Occurrence and persistence of Fusarium within styroblock and Ray Leach containers. p. 145148 In: T.D. Landis (tech. coord.). Proceedings: Combined meeting of the western forest nursery associations. USDA For. Serv. Gen. Tech. Rpt. RM-167.

James, R.L., R.K. Dumroese, and D.L. Wenny. 1990. Approaches to integrated pest management of Fusarium root disease in container- 
grown seedlings, p. 240-246. In: R. Rose, S.J. Campbell, and T.D. Landis (eds.). Target seedling symposium: Proc., combined meeting of the Western Forest Nursery Assn. and Intermountain Nursery Assn. USDA For. Serv. Gen. Tech. Rpt. RM-200, Fort Collins, Colo.

James, R.L., R.K. Dumroese, and D.L. Wenny. 1994. Observations on the association of Cylindrocarpon spp. with diseases of containergrown conifer seedlings in the inland Pacific Northwest of the United States, p. 65-78 In: R. Perrin and J.R. Sutherland (eds.). Diseases and insects in forest nurseries. Institut National de la Recherche Agronomique, Les Colloques 68, Paris, France.

James, R.L., R.K. Dumroese, and D.L. Wenny. 1997. Pathogenicity of Fusarium proliferatum in container-grown Douglas-fir seedlings, $p$. 26-33 In: R.L. James (ed.). Proc. of the third meeting of IUFRO working party S7.03-04, diseases and insects in forest nurseries. USDA For. Serv. North. Reg. For. Pest Mgt. Rpt. 97-4, Missoula, Mont.

James, R.L., R.K. Dumroese, D.L. Wenny, J.F. Myers, and C.J. Gilligan. 1987. Epidemiology of Fusarium on containerized Douglas-fir seedlings. (1) Seed and seedling infection, symptom production, and disease progression. USDA For. Serv. North. Reg. For. Pest Mgt. Rpt. 87-13, Missoula, Mont.

James, R.L. and C.J. Gilligan. 1988a. Fungal colonization of styroblock containers-Plum Creek Nursery, Pablo, Montana. USDA For. Serv. North. Reg. Forest Pest Mgt. Rpt. 88-1, Missoula, Mont.

James, R.L. and C.J. Gilligan. 1988b. Occurrence of Fusarium on Leach pine cells from the USDA Forest Service nursery, Coeur d'Alene, Idaho. USDA For. Serv. North. Reg. Forest Pest Mgt. Rpt. 88-8, Missoula, Mont.

James, R.L. and C.J. Gilligan. 1988c. Occurrence of Fusarium on the roots of nondiseased bareroot Douglas-fir seedlings-USDA Forest Service Nursery, Coeur d'Alene, Idaho. USDA For. Serv. North. Reg. Forest Pest Mgt. Rpt. 88-12, Missoula, Mont.

James, R.L., C.J. Gilligan, and V. Reedy. 1988b. Evaluation of root diseases of container conifer seedlings at the Champion Timberlands Nursery, Plains, Montana. USDA For. Serv. North. Reg. For. Pest Mgt. Rpt. 88-11, Missoula, Mont.

James, R.L., E.P. Militante, J.Y. Woo, and C.J. Gilligan. 1986. Pathogenicity of Fusarium from forest seedling nurseries on Douglas-fir and ponderosa pine seedlings. USDA For. Serv. North. Reg. For. Pest Mgt. Rpt. 86-8, Missoula, Mont.

James, R.L. and D. Sears. 1990. Bleach treatments of Leach pine cell containers-USDA Forest Service Nursery, Coeur d'Alene, Idaho. USDA For. Serv. North. Reg. For. Pest Mgt. Nursery Disease Notes No. 101, Missoula, Mont.

James, R.L. and R.L. Woollen. 1989. An evaluation of the efficacy of hot water-chemical treatments to clean styroblock containers-Champion Timberlands Nursery, Plains, Montana. USDA For. Serv. North. Reg. For. Pest Mgt. Rpt. 89-5, Missoula, Mont.

Johnson, G.F. 1935. The early history of copper fungicides. Agr. History 6:67-69.

Komada, H. 1975. Development of a selective medium for quantitative isolation of Fusarium oxysporum from natural soil. Rev. Plant Protect. Res. 8:114-125.

Kope, H.H., P.E. Axelrood, J. Sutherland, and M.S. Reddy. 1996. Prevalence and incidence of the root-inhabiting fungi, Fusarium, Cylindrocarpon and Pythium, on container-grown Douglas-fir and spruce seedlings in British Columbia. New Forests 12:55-67.

Landis, T.D. and E. van Steenis. 2000. Micronutrients: Copper. Tree Planters' Notes 49:44-48.

Mousseaux, M.R., R.K. Dumroese, R.L. James, D.L. Wenny, and G.R. Knudsen. 1998. Efficacy of Trichoderma harzianum as a biological control of Fusarium oxysporum in container-grown Douglas-fir. New Forests 15:11-21.

Nelson, P.E., T.A. Toussoun, and W.F.O Marasas. 1983. Fusarium species: an illustrated manual for identification. Penn. State Univ. Press, University Park.

Peterson, M. 1990. Sanitation of Styroblocks to control algae and seedling root rot fungi. British Columbia Min. of Forests FRDA 140, Victoria, B.C.
Peterson, M. 1991. Guidelines for the sanitation of nursery seedling containers. BC Min. of Forests Supplement to FRDA 140, Victoria, BC.

Pirone, P.P. 1978. Diseases and pests of ornamental plants. 5th ed. Wiley, New York.

SAS Institute. 1989. SAS/STAT user's guide, version 6, 4th ed. SAS Inst., Cary, N.C.

Steinberg, R.A. 1950. Growth on synthetic nutrient solutions of some fungi pathogenic to tobacco. Amer. J. Bot. 37:711-714.

Sturrock, R.N. and J.J. Dennis. 1988. Styroblock sanitization: Results of laboratory assays from trials at several British Columbia nurseries, $p$. 149-154 In: T.D. Landis (tech. coord.). Proc., combined meeting of the western forest nursery associations. USDA For. Serv. Gen. Tech. Rpt. RM-167, Fort Collins, Colo.

Tint, H. 1945. Studies in the Fusarium damping-off of conifers. 1. The comparative virulence of certain fusaria. Phytopathology 35:421-439.

van Steenis, E. 1994. Growing in copper treated containers requires greater awareness. British Columbia Min. of Forests, Victoria, BC. Seed and Seedling Ext. Topics 7(2):4-5.

Walker, J.C. 1969. Plant pathology. McGraw-Hill, New York.

Wenny, D.L. and R.K. Dumroese. 1992. A growing regime for container-grown Douglas-fir seedlings. Univ. of Idaho, Idaho For., Wildlife and Range Exp. Sta. Bul. 49, Moscow.

Wenny, D.L., Y. Liu, R.K. Dumroese, and H.L. Osborne. 1988. First-year growth of chemically root-pruned containerized seedlings. New Forests 2:111-118.

Wenny, D.L. and R.L. Woollen. 1989. Chemical root pruning improves the root system morphology of containerized seedlings. West. J. Appl. For. 4:15-17.

Woltz, S.S. and J.P. Jones. 1981. Nutritional requirements of Fusarium oxysporum: Basis for a disease control program, p. 340-349. In: Nelson, P.E., T.A. Toussoun and R.J. Cook (eds.). Fusarium: Diseases, biology, and taxonomy. Penn. State Univ. Press, University Park.

Woollen, R.L. 1986. An evaluation of a chemical root pruning technique for improving root system morphology in containerized seedlings. MS thesis. Univ. of Idaho, Moscow. 